\title{
Key Instructional Practices of Effective Elementary School Teachers of English as a Foreign Language
}

\author{
Frances Sokel ${ }^{1, *} \&$ Susan Martin ${ }^{2}$ \\ ${ }^{1}$ English Department, Shaanan Religious Academic College of Education, Haifa, Israel \\ ${ }^{2}$ Department of Education, University of Bath, UK \\ *Correspondence: English Department, Shaanan Religious Academic College of Education, Nahariya 2240740, \\ Israel.E-mail: sokel@macam.ac.il \\ Received: February 2, 2016 Accepted: March 8, $2016 \quad$ Online Published: April 17, 2016 \\ doi:10.5430/jct.v5n1p52 \\ URL: http://dx.doi.org/10.5430/jct.v5n1p52
}

\begin{abstract}
Educational improvement is at the forefront of ongoing international concern, with the quality of teaching recognised as a crucial variable in this endeavour. While in the past, instructional practices identified as effective were thought to be generic, it has become increasingly clear that the identification of contextually relevant practices is more likely to inform the notion of what constitutes effective teaching in a given context. This study addresses this issue in the context of English as a Foreign Language in Israeli elementary schools.

Placed within social and constructivist perspectives of learning, the qualitative, multiple case study explores the instructional practices of five effective teachers through classroom observations and interviews. The findings show that all teachers provide significant opportunity for knowledge construction using a variety of techniques and strategies. The notion of relevance was also a central facet of the instructional practices of some teachers.

The enquiry concludes by suggesting that the findings could be used as a basis to explore the extent to which the aspects of instruction identified feature in the practice of effective teachers in a wider context, with a view to developing a national model of pedagogy to promote much-needed and sustainable educational improvements in Israel.
\end{abstract}

Keywords: effective teachers; knowledge construction; relevance

\section{Introduction}

Ben-David (2007, p.1) states that 'The public education system is society's primary tool for ....providing basic tools that will enable future adults to make it in a modern world and in a competitive market.' Recognition of this ongoing responsibility has given rise to the 'global phenomenon' (Sahlberg 2011, p. 175) of introducing educational reforms aimed at improving educational systems and levels of educational achievement as 'direct responses' to the much publicized international PISA results (Sjøberg 2015, p.111). In some cases, such as the widely referred to example of Finland, (See Darling-Hammond, 2010), efforts to do so in recent decades are considered successful in this endeavour. However, as international test scores continue to indicate, many other countries show limited, if any, progress in improving educational outcomes. (See Center for Global Development 2015, OECD 2014). While this study focuses on the situation in Israel, the points highlighted are therefore likely to be relevant to other educational contexts worldwide.

Educational achievements were not measured using standardised tools during the decades following the foundation of the State of Israel in 1948 (Ben David, 2014). Nonetheless, the Israeli school system was recognised to have fared successfully throughout this time. More recently however, scores on international tests in the core subjects administered by the OECD highlight a stark change in this situation, as 'Average nationwide scores on international exams ... (are now) among the lowest in the developed world' (Ben-David 2014, p.4) in Israel. Likewise, despite indication of slight improvement in some areas, levels of achievement in subjects -including English, assessed by the Meitzav nationally standardised tests, continue to be regarded as inadequate (Ben-David, 2010). It is this situation that spurred the need for educational change in Israel. 
Reforms to enhance educational achievement may be implemented at varying levels. Fullan (2000, p.583) refers to the 'outside' influences of 'school districts, whole states or sets of intermediate agencies in between,' offering 'top-down' solutions for promoting and generating educational improvement'. In Israel these have included the implementation of national reform programmes providing compulsory, continued professional development courses for teachers, additional teaching hours, and the integration of technology into classrooms. Changes in curricula have also been introduced. The standards-based national English curriculum introduced in 2001 (Ministry of Education, 2001) has recently undergone extensive review whereby specified lexical items and grammatical structures to be taught have been added to the basic curriculum (Ministry of Education, 2014). Modular matriculation examinations have been introduced in several subject areas, including English, and increasing attention is given to promoting the acquisition of higher order thinking skills. In English for example, a programme focusing on developing such skills through the teaching of literature is now integral to the national high school curriculum. While attempts to improve learning by implementing change is to be embraced, it is clearly difficult to measure the extent to which such all-encompassing reforms directly impact learning outcomes.

In contrast to the more macro approach to improving educational outcomes, the body of School Effectiveness Research (SER) identifies features rooted in the internal culture of schools as key to educational improvement (Sammons, Hillman \& Mortimore, 1995). The aspect that emerges from SER as being 'at the heart of effective schooling' (Sammons, Hillman \& Mortimore, 1995, p.19) and, therefore, improved educational achievement, is the quality of teaching. This perspective continues to be at the forefront of thinking as highlighted by Hallinger, Heck and Murphy $(2014$, p.6) who state that the 'emerging consensus on the hallmark place of teaching quality in school success (whereby a)... growing body of international research confirms a direct relationship between teacher quality/effectiveness and student learning.'

While there are many elements pertaining to the notion of teacher quality and effectiveness that are likely to enhance learning outcomes, the perception that 'instructional practices are conceptualized as having the most proximal association with student learning,' (Palardy \& Rumberger, 2008, p.114), is particularly prominent. However, despite the recognition afforded to the importance of instructional practice in promoting educational improvement, there is much discussion as to the nature of that practice. As Gamoran $(2011, \mathrm{p} .1)$ highlights, 'The research is equivocal as to what effective teachers do that makes them more successful than others.' It is in light of this perception that the multiple case study presented in this article set out to answer the research question: 'How do effective teachers of English in the Israeli (Jewish sector) elementary school facilitate learning?'

\subsection{Developments in Teacher Effectiveness Research: An Overview}

Studies into effective teachers and teaching practices that form the body of knowledge known as Teacher Effectiveness Research (TER) have a long history, as illustrated by the earliest recorded study on this topic by Kratz in 1896. Prominent changes and developments throughout the evolution of TER are evident. The following section traces some key developments, and highlights factors that have given rise to what is recognised to constitute effective teaching today.

The earliest research tended to be descriptive (Turner-Bisset, 2001), highlighting personality traits and characteristics of teachers (Medley, 1972, Brophy \& Good, 1986, Harris, 1998). Teachers identified as 'helpful' and 'kind' (Kratz, 1896) were considered the best teachers. Such studies were highly subjective as they were based on the opinions of pupils (Kratz, 1896), and those of professionals or experts in the field (Medley, 1972, Brophy \& Good, 1986). Hence 'an ideal teacher met subjective standards of excellence determined by selected, significant others' (Cruickshank \& Haefele, 2001, p.26).

The limited usefulness of studies based solely on personal opinion with no measurement of teacher effects (Medley, 1972) on the mastery of academic skills (Rosenshine \& Berliner, 1978) became increasingly apparent. As 'educationists attempted to move instructional skills from a largely intuitive craft practice on to a more scientific basis' (Campbell, Kyriakides, Muijs, \& Robinson, 2003, p.347), the focus of research into effective teachers and teaching '...shifted from teachers' personal traits to their teaching behaviours' (Brophy 1986, p.1069). Hence the rise of the process-product paradigm of TER.

Process-product research studies 'tended to follow a common general paradigm,' (Shalveson, Webb \& Burstein, 1986, p.51), focusing on language or mathematics instruction in a large number of primary school classrooms in the USA and the UK. The studies 'sought teacher behaviours that predicted or preferably caused growth in student knowledge and skills,' (Harris, 1998, p.171) whereby indication of the extent of such growth was gleaned from achievement test scores (Doyle, 1977). Process-product research thus served to measure the direct effects of teaching on learning outcomes using specified instructional practices. 
Two areas of practices and procedures emerged from process-product as pivotal to effective teaching. Firstly the assumption that the more time allocated to the instruction of a specific subject, the more subject matter will be covered by the teacher and the more learning will take place, was prominent. Secondly the teacher's orderly provision of academic activity through 'whole class instruction' (Good \& Grouws, 1977, p.53) and 'seatwork' (Rosenshine, 1983, p.346) as pupils work on 'a fairly common series of linear tasks' (Rosenshine \& Berliner, 1978, p.11) known as active instruction was seen as key to effective teaching.

These practices lean on key tenets of behaviorist learning theory, identifying the learner as a 'passive recipient of knowledge' (Carnell \& Lodge, 2003, p.11), in which the mind is viewed as 'a black box ' where 'we can accurately judge what goes in (stimulus) and what comes out (response)' (Bodner, 1986, p.876). Learners therefore engage in the shallow processing of knowledge transmitted by the teacher, only to be later reproduced - primarily on tests.

Despite the recognition of its contribution to the field of teaching, a sense of dissatisfaction with process-product research surfaced among professionals (Shulman, 1986). This phenomenon may be attributed to two significant developments in the fields of learning and teaching during the relevant period: a) the emergence and increasing acceptance of constructivist learning theories and b) the growing need for the codification of the professional knowledge base for teachers that, in turn, led to the understanding that context specific teachers' knowledge is essential in promoting effective teaching, as highlighted by Shulman's (1987) identification of Pedagogical Content Knowledge. Both aspects are discussed below.

\subsection{Constructivist Learning Theories}

Constructivism is described by Cholewinski $(2009$, p.284) as 'a theory that aims to explain what knowledge is, and how it is acquired,' offering 'a powerful challenge' to the behaviourist perspective that lead to a significant 'paradigm shift in educational design and practices away from 'traditional' methods' (Cholewinski 2009, p.283). While different interpretations and versions of constructivism have emerged, the essence of the constructivist perspective of learning may 'be summarized in a single statement: Knowledge is constructed in the mind of the learner.' (Bodner 1986, p.876).

Knowledge construction can be seen as a process that takes place along a continuum. Initially, learners are exposed to new information through varying experiences and situations that in the formal learning environment might be achieved through focused instruction. The new information is linked by the learner to existing knowledge acquired through prior instruction and experiences. Doing so enables learners to comprehend new, incoming information by forming new associations and altering those that existed previously within their knowledge networks or structures (King, 1994). This perception of the way in which knowledge is acquired serves as the central tenet of the different aspects of Constructivist Learning Theory.

Social Constructivism, the aspect of Constructivist Learning Theory central to this study, is rooted in the work of the Russian theorist Lev Vygotsky. Vygotsky contends that 'the developmental process (is) towed by the learning process' (Blanck, 1990, p.50), whereby the learning process encountered by the child '(leads)... development rather than follow(s) it' (Bodrova, 1997, p.20). This process is recognised to benefit from and depend largely on 'social practices' identified by Lave and Wenger (1996, p.147) as 'the fundamental form of learning.' Hence in the formal learning environment, it is clearly the teacher who bears chief responsibility for leading the learning process through social interaction with the pupils.

Reusser (2001, p.2058) extends this notion further in noting that learning takes place though social interaction that is 'embedded in the cultural surroundings in which the activity takes place.' It is this perception that promotes the view that learning is not only social in nature, but that social interaction must be relevantly situated if it is to be effective. Social Constructivism thus laid the foundation for Situated Learning Theory. Anderson, Reder and Simon (1996, p.5) note that 'Situated learning... emphasizes the idea that much of what is learned is specific to the situation in which it is learned.' As such, learning is likely to be more meaningful if it takes place within a situation that, at the very least, reflects its relevance to the world of the learner beyond the school environment, an observation that has made 'a significant impact on educational thinking' (Herrington \& Oliver, 1995,p.1).

\subsection{The Importance of Context}

In lacking 'context specificity' (Hopkins \& Reynolds, 2001, p.464), process-product research failed to 'produce the kind of validated consensus about effective teaching that teachers can use to guide their practice intelligently' (Nuthall \& Alton-Lee, 1990, p.552) in specific contexts. Hence, subsequent research studies into effective teaching place emphasis on the examination of 'the flow and texture of classroom events' as they occur (Doyle, 1977, p.176), and 'tend to look for criteria of effectiveness within the situation' (Shulman, 1986, p.19). Contextual aspects 
influencing the instructional practices employed by teachers include such as subject matter and learner-related characteristics and are, in turn, embedded within the broader contextual influences of the school, community and culture (Ross, Cornett \& McCutcheon, 1992).

\subsection{Learner Engagement}

In acknowledgement of the importance of context in research if it is to serve the purpose of furthering the understanding of what constitutes effective teaching, an examination of studies set in contexts that bear a significant degree of relevance to this one -English language instruction in Israeli elementary schools, was conducted. The review, which included all studies set in primary schools, some focusing on reading instruction and some in the classrooms of English language learners, revealed that learner engagement is a pre-requisite for improving academic achievements, and is, as such, closely associated with effective teaching practice. (Pressley, Wharton-McDonald, Allington, Collins Block, \& Morrow, 1998, Allington, 2002, Taylor, Pearson, Peterson \& Rodriguez, 2003, Graves, Gersten \& Haager, 2004, Pressley, Raphael, Gallagher \& DiBella, 2004).

Nystrand and Gamoran (1991) identify two contrasting forms of learner engagement: procedural and substantive. Procedural engagement refers primarily to behaviours that can be clearly observed and therefore identified by the teacher, such as completing written exercises (Gettinger \& Seibert, 2002, p.3). Substantive engagement, according to Gettinger and Seibert (2002, p. 3) 'transcends procedural engagement' in that it 'involves a sustained personal commitment to and engagement in the content of instruction' that in turn leads to 'substantive understanding' (Newmann, Wehlage \& Lamborn, 1992,p.12). Nystrand and Gamoran (1991, p.262) highlight that 'Significant academic achievement is not possible without sustained, substantive engagement.' Newmann, Wehlage and Lamborn (1992) identify authenticity in instruction as being central to the promotion of substantive engagement in the classroom.

\subsection{Authenticity in Instruction}

According to Wehlage, Newmann and Secada (1996), teachers direct teaching and learning through two primary tasks: instruction and assessment of pupil performance. In order to appreciate what the notion of authenticity in these aspects of educational activity might entail, Newmann, Marks and Gamoran $(1996,282)$ suggest that we look at the demands of the real world and consider 'the kinds of mastery demonstrated by successful scientists, musicians, entrepreneurs, politicians, craftspeople.......We assume that success in these endeavors usually represents significant and worthwhile intellectual work.' This perception of authenticity in an educational context, whereby activity undertaken in the classroom that reflects the intellectual demands of real life situations is embraced, underlies Newmann, Marks and Gamoran's (1996) model of 'Authentic Pedagogy.'

Newmann, Marks and Gamoran's (1996) model is seated firmly in the theoretical perspectives of Social Constructivism and Situated Learning, and may be seen as a watershed, spurring interest, further research and/or educational reform that embrace the notion of authenticity in instruction in promoting substantive engagement and, therefore, learning in varied contexts. Notable examples include Holland (Roelofs \&Terwel, 1999) in the late 1990s, and Queensland (Lingard, Hayes \& Mills, 2003) and New South Wales (NSW DET 2003) in Australia in the following decade.

The model highlights three main aspects: the construction of knowledge by the learner as an active participant in the learning process, the need for disciplined inquiry whereby learners engage in in-depth learning through elaborated communication (Newmann, Marks \& Gamoran, 1996), and the value of what is learned and how, beyond the classroom. These categories served as the basis for collecting and analysing the data in this study.

\section{Method}

In the attempt to identify key instructional practices that are likely to contribute to improved learning outcomes in the context at the focus of this study, a multiple case study of a qualitative nature was conducted.

\subsection{Participants}

The participants were five English teachers in four Israeli elementary schools of varied settings and populations in the Jewish sector. The teachers were selected in light of the fact that they were recognised as being effective in their practice, indicated by their pupils' consistently above-average scores attained on national standardised tests over recent years, the opinions of their respective School Principals and Regional Inspectors for English. All five teachers gave their informed consent to providing the data for this study. 


\subsection{Data Collection and Analysis}

The data were collected through unstructured classroom observations and two sets of interviews with the teachers. Between 4-6 lessons over 2 or 3 visits were observed by the researcher in a non-participatory capacity, during which detailed notes of the utterances and actions of both teachers and pupils were made as they occurred. The teachers were first interviewed at the end of each visit in relation to each lesson observed. These interviews served as a means of gaining insight into the underlying rationale of key aspects of the activity recorded in the preceding classroom observations. The first questions invited the teachers to reflect on the lesson in light of their planning and execution overall. Subsequent questions, tailored to relate to observed activity within a specific lesson, were posed to determine the extent to which key aspects of authentic instruction as identified earlier, featured in the rationale of each teacher's practice. The data collected from both the observations and the first set of interviews were subsequently coded using one of the most frequently used analytical tools (Corbin \& Strauss, 2008:73) - making constant comparisons between segments of data. Each information item was placed into an existing category that had emerged previously in the process, or established a new category to accommodate the data as appropriate.

A second set of interviews was conducted with each teacher in turn following analysis of the data collected so far, thereby relating to specific issues for each teacher that came up after the categories had been established. The purpose of these interviews was twofold. Firstly in confirming the prominent practices as observed, interpreted and listed by the researcher, the teachers' responses served as respondent validation. Secondly, this series of interviews enabled the researcher to gain insight into the rationale and concerns behind the prominent practices that arose from the analysis of the data collected.

Upon completion of the analysis of the data from each participant individually, a cross-case analysis whereby 'emphasis is on comparing... different examples and the contrasts found between and among the cases' (Thomas 2011, p.153) was conducted. The instructional practices that emerged in the course of data collection and analysis were counted and classified as occurring frequently (used at least once, and often several times, in at least half of the lessons observed), infrequently (used in less than half of the lessons observed), or not used at all.

\section{Findings}

Analysis of the data revealed the instructional practices identified as being executed frequently by the teachers fall under two main headings: the facilitation of knowledge construction and the provision of relevance in learning. The following section highlights the different ways in which each aspect was catered for in practice, and, in addition, relates to the frequent practice of promoting class discussion.

\subsection{Facilitating Knowledge Construction}

\subsubsection{Prior Knowledge}

In facilitating the construction of new knowledge the teachers frequently activated pupils' relevant prior knowledge. All five teachers made direct connections between pupils' prior knowledge and the content of the lesson. For example, as part of a lead-in to the kitchen vocabulary items to be introduced, one teacher stated 'I'm going to put on the board (pictures of) things that everyone has in the kitchen.' In this way she was, in essence, setting the scene for the new vocabulary by guiding pupils to make the connection to their own kitchens and the contents. Similarly, when working on a text about the origin of pizza, another teacher pointed out that 'Queen Margarita reminds us of pizza margarita' -a widely known variety and popular choice in pizza restaurants in Israel. In other instances teachers posed questions to elicit pupils' relevant prior knowledge. Closed questions whereby there was a right/wrong answer were used frequently. For example, in referring to birthday customs discussed in connection with a text read in the previous lesson, one teacher asked 'What do they do in Canada for luck?' Other questions were more open-ended, therefore allowing pupils to relate to their relevant personal experiences such as 'How do you celebrate your birthday? Where do you go? What do you do?' The technique of prompting through unfinished sentences to stimulate pupils' recollection of previously encountered information also featured regularly in lessons observed. In reviewing vocabulary one teacher said: 'If my dog is not healthy I take him to the ....' The pupils then responded appropriately in chorus with 'vet'.

\subsubsection{Higher Order Thinking Skills}

Fostering the use and development of higher order thinking skills in enabling the construction of knowledge was also accommodated frequently in the practice of three teachers. One teacher noted succinctly that providing opportunity for her pupils to become 'thinking people' is a priority, while another teacher stated that challenging her pupils by 'expanding what they need to know' and encouraging them 'to reach conclusions' is integral to her practice. Such 
opportunities were provided primarily by asking 'Why?' or 'How?' questions to promote the skills of reasoning and explaining ideas and opinions through in-depth discussion. One teacher, for example, asked pupils to consider if and why an unexpected response to a closed question was suitable. In examining a table recording the weekly routine of a boy and eliciting information gleaned from the table, another teacher asked pupils how they know the boy doesn't play football on a given day. In order to respond correctly pupils needed to explain how they had inferred such a conclusion from the information given in the table.

\subsubsection{Instructional Coherence}

Providing coherent instruction, an additional practice that facilitates knowledge construction, was evident in the lessons of four teachers on a regular basis, and executed in three main ways. Three teachers provided lessons focusing on one topic- such as Robin Hood and birthdays. The lessons of two teachers displayed continuity as the second aspect of instructional coherence, whereby each stage or activity in the lesson served as the foundation for the next. Both elements are compatible with and integral to the notion of instructional coherence as identified by Chen and $\mathrm{Li}$ (2010, p.713). Two teachers scaffolded instruction to support pupils in executing challenging tasks such as completing a language exercise and comprehending the difference between ordinal and cardinal numbers in English as the third aspect of instructional coherence exercised on frequent occasions.

All four teachers who provided elements of instructional coherence placed significant emphasis on and offered varying reasons for both the need to and the underlying rationale for doing so in the follow-up interviews. One teacher recognised the support that logical structure and scaffolding offer to less-able pupils. Another teacher noted that providing logic and order in her lessons helps to keep both herself and her pupils focused. The main purpose for scaffolding instruction cited by a third teacher, who uses the technique of scaffolding to lead pupils towards reaching their own conclusions about issues, resonates with the observations of Wharton-McDonald, Pressley and Hampston (1998) whereby the effective teacher scaffolds students' thought processes by posing questions. A fourth teacher noted that she projects her own need for structure and logic into her teaching by planning lessons based on one area of focus. Hence, while both the rationale for and the techniques used in providing instructional coherence differ among the teachers, the findings indicate that the provision of instructional coherence as an overall concept is a significant element in the practice of the effective teachers studied.

\subsection{Relevance}

The study revealed that relevance of instruction to and/or for learners featured less frequently than the facilitation of knowledge construction in the practice of the teachers overall. Nonetheless, three teachers did provide frequent learning experiences of relevance through practices that fall into two main categories.

Firstly, two teachers provided frequent instruction whereby the content or topic was relevant to the pupils' world at varying levels. This included the topics of assassinated Prime Minister of Israel, Yitzhak Rabin, which relates to the national identity of pupils, the Simpsons as familiar television characters of relevance to peer culture and pupils' personal interests, and emotions and experiences of the pupils themselves such as basing a lesson on a popular song entitled 'Beautiful' that served as the springboard for a discussion about believing in oneself.

The second aspect of relevance - the promotion of autonomy as an increasingly necessary life skill, was evident in the practice of two teachers. Pupils were offered opportunities to make choices in the lessons of both teachers, be it in the quantity of work to be completed - specifically the number of questions to be answered, or in engaging in activities of their choice. One teacher offered regular opportunity for pupils to manage their own time and evaluate their own performance. The former was accommodated by listing tasks for the lesson on the board before the lesson started, so that when pupils entered the English classroom they knew what was expected of them for that lesson, each deciding how much time to allocate to each task. In providing opportunity for self-evaluation, pupils were asked to review their completed written assignments in class and, if satisfied with their work, to place them in a designated basket for the teacher to check. If they felt their work needed further revision they were expected to do so at home and submit it the following day.

\subsection{Whole Class Discussion}

The practice of whole class discussion mediated by the teacher, that could be considered a vehicle for promoting some aspects of knowledge construction and relevant instruction mentioned above, was prominent in the lessons observed. Four of the five teachers provided frequent opportunities for pupils to activate prior knowledge and consider topics and issues in depth through discussion in whole-class forums. The discussions were conducted in English as the target language at an appropriate level. Thus, while pupils may not have been able to express themselves orally at the same level of articulation or in the same depth as they may have done in their mother-tongue, 
the discussions facilitated consideration of topics and issues by encouraging pupils to share and extend their knowledge, ideas and opinions accordingly.

Two main purposes served by class discussions emerged from the follow-up interviews. Firstly they enabled teachers to assess, activate and/or establish pupils' relevant prior knowledge of the topic at hand - for example by discussing familiar characters in a picture or reviewing the content of a text read previously. Secondly, as in the practice of two of the teachers, class discussions were used to promote the development and use of higher order thinking skills- by such as predicting the content of a text and offering opinions on a subject. In the interviews two teachers made reference to the point that facilitating regular discussion gives pupils opportunity to develop their thinking abilities, a perception compatible with that of Stanulis, Little and Wibbens (2012, p. 34), who reason that 'High level discussions can provide teachers with access to student thinking and understanding, promote higher order thinking...'

The findings that emerged from this study, while of great interest in themselves, also promote further thought and consideration.

\section{Conclusions and Implications}

The substantial effort and resources that have been and continue to be invested in attempting to improve educational achievements in Israeli schools have not yet yielded the desired outcomes. It is therefore crucial to consider perspectives and issues that have not, to date, been given adequate attention in the quest to improve learning. The quality of teachers and teaching is a key aspect.

Pedagogues and policy makers must acknowledge that substantial improvement of educational outcomes in Israel is primarily dependent on effective teaching and teachers, and subsequently explore ways to invest more intensively in improving instructional practice.

Ladwig (2005, p.71) states that pedagogy cannot be improved in the absence of a model to guide and serve as a focus for appropriate change. The key practices identified in this study stem from, as will be recalled, contemporary learning theory and instructional ideas pertinent to such theory, which have shown to serve varying contexts. Therefore, although the relevance of these frameworks was illustrated within the context of English teaching in the Israeli elementary school (Jewish sector), there is significant possibility that the practices identified would be applicable to the broader context in which this study is placed. In the quest to enhance learning outcomes in Israel overall, and acknowledging that a focus on pedagogical practice is called for, this perspective cannot be overlooked.

The conclusions drawn from this study could serve as a framework within which to further investigate and identify the main practices employed by the wider community of a larger, more varied sample of effective teachers of both English and other subjects in the Israeli school system. The findings of such a study would provide a significant basis upon which to develop a much-needed contemporary model of pedagogy in which to frame a more authentic and meaningful learning experience that reflects the needs of the Israeli educational context and secures the foundations of an educational system that promotes enhanced achievement for the future generations of Israel.

\section{References}

Allington, R. L. (2002). What I've learned about effective reading instruction from a decade of studying exemplary elementary classroom teachers. Phi Delta Kappan, 83(10), 740-747. http://dx.doi.org/10.1177/003172170208301007

Anderson, J. R., Reder, L. M., \& Simon, A. H. (1996). Situated learning and education. Educational Researcher, 25(4), 5-11. http://dx.doi.org/10.3102/0013189X025004005

Ben-David, D. (2007, December). The educational tower of PISA. Ha'aretz, Retrieved from http://www.tau.ac.il/ danib/index_articles.html

Ben-David, D. (2010). Israel's educational achievements: Updated international comparisons. (Policy Paper Series, Policy Paper No. 2011.12) Tel Aviv, Taub Center for Social Policy Studies in Israel. Retrieved from http://taubcenter.org.il/tauborgilwp/wpcontent/uploads/E2010Educational Achievements-Chapter.pdf

Ben-David, D. (2014). A picture of the nation, Israel's society and economy in figures. Tel Aviv: Taub Center for Social Policy Studies in Israel. Retrieved from http://taubcenter.org.il/state-of-the-nation-picture-2014/

Blanck, G. (1990). Vygotsky: The man and his cause. In L. C. Moll (Editor), Vygotsky and education: Instructional implications and applications of sociohistorical psychology (pp. 31-58). USA: CUP. 
http://dx.doi.org/10.1017/CBO9781139173674.003

Bodner, G. M. (1986). Constructivism: A theory of knowledge. Journal of Chemical Education, 63, 873-878. http://dx.doi.org/10.1021/ed063p873

Bodrova, E. (1997). Key concepts of Vygotsky's theory of learning and development. Journal of Early Childhood Teacher Education, 18(2), 16-22. http://dx.doi.org/10.1080/1090102970180205

Brophy, J. (1986). Teacher influences on student achievement. American Psychologist, 41(10), 1069-1077. http://dx.doi.org/10.1037/0003-066X.41.10.1069

Brophy, J., \& Good, T. (1986). Teacher behavior and student achievement. In M. C. Wittrock (Editor), Handbook of research on teaching ( $3^{\text {rd }}$ edition). (pp. 28-375). New York: MacMillan.

Campbell, R. J., Kyriakides, L., Muijs, R. D., \& Robinson, W. (2003). Differential teacher effectiveness: Towards a model for research and teacher appraisal. Oxford Review of Education, 29(3), 347-362. http://dx.doi.org/10.1080/03054980307440

Carnell, E., \& Lodge, C. (2003). Supporting effective learning. London: Paul Chapman Publishing.

Center for Global Development. (2015). Ambitious learning goals need audacious new approaches. (Vision Document No. 2.) UK: Research on Improving Systems of Education (RISE), Retrieved from http://www.ukcds.org.uk/sites/default/files/content/resources/RISE\%20Vision\%20document\%202.pdf

Chen, X., \& Li, Y. (2010). Instructional coherence in Chinese mathematics classroom-A case study of lessons on fraction division. International Journal of Science and Mathematics Education, 8, 711-735. $\mathrm{http}: / / \mathrm{dx}$. doi.org/10.1007/s10763-009-9182-y

Cholewinski, M. (2009). An introduction to constructivism and authentic activity. Nagoya University of Foreign Studies Journal of the School of Contemporary International Studies, 5, 283-316.

Corbin, J., \& Strauss, A. (2008). Basics of qualitative research. Los Angeles: Sage Publications.

Cruickshank, D. R., \& Haefele D. (2001). Good teachers, plural. Educational Leadership, 58(5), 26-30.

Darling-Hammond, L. (2010). What we can learn from Finland's successful school reform. NEA Today Magazine, Issue 5 (October/November). http://www.nea.org/home/40991.htm

Doyle, W. (1977). Paradigms for research on teacher effectiveness. Review of Research in Education, 5, 163-198. http://dx.doi.org/10.2307/1167174

Fullan, M. (2000). The three stories of educational reform. The Phi Delta Kappan, 81(8), 581-584.

Gamoran, A. (2011). Evidence-based investments in education: What research tells us about strategies to elevate student academic performance. Paper presented at The Herbert M. Singer Conference on Socioeconomic Impact of Education. Tel Aviv. September 18.

Gettinger, M., \& Seibert, J. K. (2002). Best practices in increasing academic learning time. In A. Thomas \& J. Grimes (Eds.). Best practices in school psychology (4th edition). (pp. 773-788). Bethesda, MD: National Association of School Psychologists.

Good, T., \& Grouws, D. (1977). A process-product study in fourth-grade mathematics classrooms. Journal of Teacher Education, 28(3), 49-54. http://dx.doi.org/10.1177/002248717702800310

Graves, A. W., Gersten, R., \& Haager, D. (2004). Literacy instruction in multiple- language first grade classrooms: Linking student outcomes to observed instructional practices. Learning Disabilities, Research and Practice, 19(4), 262-272. http://dx.doi.org/10.1111/j.1540-5826.2004.00111.x

Hallinger, P., Heck, R. H., \& Murphy, J. (2014). Teacher evaluation and school improvement: An analysis of the evidence. Educational Assessment Evaluation and Accountability, 26, 5-28. http://dx.doi.org/10.1007/s1 1092-013-9179-5

Harris, A. (1998). Effective teaching - A review of the literature. School Leadership and Management 18(2), 169-183. http://dx.doi.org/10.1080/13632439869628

Herrington, J., \& Oliver, R. (1995). Critical characteristics of situated learning: Implications for the instructional design of multimedia. In J. Pearce \& A. Ellis. (Eds.), Learning with technology, ASCILITE'95 Conference Proceedings, (pp. 253-262). Melbourne: ASCILITE.

Hopkins, D., \& Reynolds, D. (2001). The Past, present and future of school improvement: Towards the third age. 
British Educational Research Journal, 27(4), 459-474. http://dx.doi.org/10.1080/01411920120071461

King, A. (1994). Guiding knowledge construction in the classroom: Effects of teaching children how to question and how to explain. American Educational Research Journal, 31(2), 338-368. http://dx.doi.org/10.3102/00028312031002338

Kratz, H. E. (1896). Characteristics of the best teachers as recognized by children. Pedagogical Seminary, 3, 413-418. http://dx.doi.org/10.1080/08919402.1896.9943604

Ladwig, J. G. (2005). Monitoring the quality of pedagogy. Leading and Managing, 11(2), 70-83.

Lave, J., \& Wenger, E. (1996). Practice, person, social world. In H. Daniels (Ed.), An Introduction to Vygotsky (pp. 143-150). UK: Routledge.

Lingard, B., Hayes, D., \& Mills, M. (2003). Teachers and productive pedagogies: Contextualizing, conceptualising, utilizing pedagogy. Culture \& Society, 11(3), 399-424.

Medley, D. M. (1972). Early history of research on teacher behavior. International Review of Education, 18(4), 430-439. http://dx.doi.org/10.1007/BF01450306

Ministry of Education. (2001). English curriculum for all grades: Principles and standards for learning English as a foreign language in Israeli schools. Israel, Ministry of Education.

Ministry of Education. (2014). Revised English curriculum: Principles and standards for learning English as an international language for all grades. Israel, Ministry of Education.

Newmann, F. M., Marks, H. M., \& Gamoran, A. (1996). Authentic pedagogy and student performance. American Journal of Education, 104(4), 280-312. http://dx.doi.org/10.1086/444136

Newmann, F. M., Wehlage, G. G., \& Lamborn, S. L. (1992). The significance and sources of student engagement. In F. M. Newmann, (Ed.), Student Engagement and Achievement in American Secondary Schools (pp. 11-39). New York, Teachers College Press.

NSW DET. (2003). Quality Teaching in NSW Public Schools, Discussion Paper. Sydney, New South Wales: Department of Education and Training. Retrieved from https://www.det.nsw.edu.au/proflearn/docs/pdf/qt_EPSColor.pdf

Nuthall, G., \& Alton-Lee, A. (1990). Research on teaching and learning: Thirty years of change. The Elementary School Journal, 90(5), 547-570. http://dx.doi.org/10.1086/461632

Nystrand, M., \& Gamoran, A. (1991). Instructional discourse, Student engagement and literature achievement. Research in the Teaching of English, 25(3), 261-289.

OECD. (2014). PISA 2012 Results in Focus: What 15-Year-Olds Know and What They Can Do with What They Know. Retrieved from http://www.oecd.org/pisa/keyfindings/pisa-2012-results-overview.pdf

Palardy, G. J., \& Rumberger, R. W. (2008). Teacher effectiveness in first grade: The importance of background qualifications, attitudes, and instructional practices for student learning. Educational Evaluation and Policy Analysis, 30(2), 111-140. http://dx.doi.org/10.3102/0162373708317680

Pressley, M., Raphael, L., Gallagher, J. D., \& DiBella, J. (2004). Providence-St. Mel school: How a school that works for African American students works. Journal of Educational Psychology, 96(2), 216-235. http://dx.doi.org/10.1037/0022-0663.96.2.216

Pressley, M., Wharton-McDonald, R., Allington, R., Collins Block, C., \& Morrow, L. (1998). The nature of effective first-grade literacy instruction. (CELA Research Report No. 11007). New York, The National Research Centre on English Learning and Achievement. Retrieved from http://www.albany.edu/cela/reports/pressley1stgrade11007.pdf

Reusser. K. (2001). Co-constructivism in educational theory and practice. In N. J. Smelser and P. B. Baltes (Eds.), International encyclopedia of the social and behavioral sciences. (pp. 2056-2062). Oxford, Elsevier Science. http://dx.doi.org/10.1016/b0-08-043076-7/02408-6

Roelofs, E., \& Terwel, J. (1999). Constructivism and authentic pedagogy: State of the art and recent developments in the Dutch national curriculum in secondary education. Journal of Curriculum Studies, 31(2), 201-227. http://dx.doi.org/10.1080/002202799183232

Rosenshine, B. (1983). Teaching functions in instructional programs. The Elementary School Journal, 83(4), 
335-351. http://dx.doi.org/10.1086/461321

Rosenshine, B. V., \& Berliner, D. C. (1978). Academic engaged time. Journal of Teacher Education, 4, 3-16. http://dx.doi.org/10.1080/0260747780040102

Ross, E. W., Cornett, J. W., \& McCutcheon, G. (1992). Teacher personal theorizing and research on curriculum and teaching. In E. W. Ross, J. W. Cornett, \& G. McCutcheon (Eds.), Teacher personal theorizing: Connecting curriculum practice, theory and research, (pp.3-19). USA: State University of New York Press.

Sahlberg, P. (2011). The fourth way of Finland. Journal of Educational Change, 12, $173-185$. http://dx.doi.org/10.1007/s10833-011-9157-y

Sammons, P., Hillman, J., \& Mortimore, P. (1995). Key characteristics of effective schools: A review of school effectiveness research. London: OFSTED.

Shalveson, R. J., Webb, N. W., \& Burstein, L. (1986). Measurement of teaching. In M. C. Wittrock (Ed.), Handbook of research on teaching, (3rd edition). (pp. 50-58). New York, MacMillan.

Shulman, L. S. (1986). Those who understand: Knowledge growth in teaching. Educational Researcher, 4-14. http://dx.doi.org/10.3102/0013189X015002004

Shulman, L. S. (1987). Knowledge and teaching: Foundations of the new reform. Harvard Educational Review, 57(1), 1-23. http://dx.doi.org/10.17763/haer.57.1.j463w79r56455411

Sjøberg, S. (2015). PISA and global educational governance - A critique of the project, its uses and implications. Eurasia Journal of Mathematics, Science and Technology, 11(1), 111-127.

Stanulis, R. N., Little, S., \& Wibbens, E. (2012). Intensive mentoring that contributes to beginning elementary teachers' learning to lead classroom discussion. Teaching and Teacher Education, 28, 32-43.

Taylor, B. M., Pearson, P. D., Peterson, D. S., \& Rodriguez, M. C. (2003). Reading growth in high poverty classrooms: The influence of teacher practices that encourage cognitive engagement in literacy learning. The Elementary School Journal, 104(1), 3-28. http://dx.doi.org/10.1086/499740

Thomas, G. (2011). How to do your case Study. London: Sage Publications.

Turner-Bisset, R. (2001). Expert teaching. Great Britain, David Fulton Publishers.

Wehlage, G. C., Newmann, F. M., \& Secada, W. G. (1996). Standards for authentic achievement and pedagogy. In F. M. Newmann and Associates (Eds.), Authentic achievement: Restructuring schools for intellectual quality, (pp.21-48). San Francisco, Jossey-Bass.

Wharton-McDonald, R., Pressley, M., \& Hampston, J. M. (1998). Literacy instruction in nine first-grade classrooms: Teacher characteristics and student achievement. The Elementary School Journal, 99(2), 101-128. http://dx.doi.org/10.1086/461918 